\title{
'My voice shall ring in your ears': the acousmatic voice and the timbral sublime in the Gothic Romance ${ }^{1}$
}

\author{
Dr Matt Foley
}

University of Stirling

\begin{abstract}
... you shall rise rattling in your chains, and rustling from your straw, to greet me, yet still you shall have the curse of sanity, and of memory. My voice shall ring in your ears till then, and the glance of these eyes shall be reflected from every object, animate or inanimate, till you behold them again.
\end{abstract}

(Maturin 1998: 44)

Recorded in the account of the Englishman Charles Stanton - a found manuscript which forms one of the six embedded tales of Charles Maturin's Melmoth the Wanderer (1820) this promise of eternal imprisonment, horror and auditory persecution is delivered by the infernal Melmoth to a beleaguered Stanton as he is imprisoned in a continental asylum. With a darkly bleak cell as its setting, the passage cited here invokes a number of recognised symbols of Gothic entrapment. Stanton will be enchained, he is warned, throughout his sickening descent into depravity, with his every move paroled by Melmoth's gaze: a paralysing look that strips Stanton of his humanity but not his reason. The gaze and the voice - the theorizing of which has so fascinated Jacques Lacan and his acolytes in the Slovenian school of psychoanalysis ${ }^{2}$ - are consistently the bearers of horror and persecution in Maturin's novel. Of particular interest to the argument that will be developed below regarding the acoustics of the Gothic Romance is that the agony of Stanton's bodily enchainment is redoubled by an auditory assault from a seemingly sourceless voice. Stanton is threatened not just by the paralyzing gaze of the fiend before him but he must bear also the uncanny peal of Melmoth's disembodied voice and its a-symbolic 'ring'. This early encounter between Stanton and Melmoth sets a precedent for the sonic concerns of Maturin's novel more widely, foreshadowing, as it does, the verbal assaults of the Inquisition that occur later in 'The Spaniard's Tale'. While, drawing from the theories of Michel Foucault, ${ }^{3}$ the importance of sight and obscurity to its aesthetic forms has been highlighted frequently in studies of the early British Gothic, the object voice's role in these fictions has been considered more scarcely. As I hope to prove here, the obscured or sourceless voice as a means of auditory persecution is an important mechanism, not only in the male Gothic of the originate period of the British Gothic Romance, but, too, in the novels of Ann Radcliffe. Radcliffe's tales of terror, which are exemplary of the Female Gothic mode, tarry with the object voice more cautiously than Maturin's fiction; while in the creature's rejection by society in Mary Shelley's Frankenstein (1818/1831) - another Gothic horror of the early

\footnotetext{
${ }^{1}$ This article is forthcoming in Horror Studies; the version provided here has not yet been subject to any necessary correction or editing for publication.

2 The two book-length studies by this Lacanian school are Renata Salecl and Slavoj Žižek's (eds. 1996) Gaze and Voice as Love Objects, Durham, NC: Duke UP and, more recently, Malden Dolar's (2006), A Voice and Nothing More, Cambridge, MA: MIT Press. A further essential text is Žižek's (2001) Enjoy Your Symptom!, $2^{\text {nd }}$ ed., Routledge: London in which he provides a seminal reading of the object voice in art.

${ }^{3}$ Notable examples of extended Foucauldian readings of the Gothic Romance include Robert Miles' (2002) Gothic Writing 1750-1820: A Genealogy, $2^{\text {nd }}$ ed., Manchester: Manchester University Press and Dale Townshend's (2007) The Orders of the Gothic: Foucault, Lacan, and the Subject of Gothic Writing 1764-1820, New York: AMS Press.
} 
nineteenth-century - there is a particularly important turning point that marks a change in register from the voice as an invoker of desire in Radcliffe to its more visceral incarnation as excess and drive in Maturin.

In the close readings that follow of the timbral horrors of Melmoth and of the voice in its ambiguous status as a disembodied object in Radcliffe, it becomes clear that there is a complex appropriation of the voice, too, as an ethical agent of law in each text; where the differences between these appropriations may be drawn from broader and contemporaneous distinctions between terror and horror. In its scenes of degradation and interrogation, Melmoth invokes a negative timbral sublime - an overwhelming textual/auditory excess in the classical tradition of Longinus' understanding of sublime writing - so as to approach what, theoretically, Dolar describes as 'the voice beyond logos, the voice beyond law' (2015: 45). It is through this sleight of hand that the interrogative voices of Melmoth attempt to dominate those to whom they call. Refusing a sanitizing narrative arch, Melmoth the Wanderer draws attention to the object voice's role in sustaining the perverse laws of the Inquisition; the voice becomes a sublime object, one which Melmoth adopts in his attempts at satanic seduction. In Radcliffe's literature of terror, the disembodied voice is shown, consistently, to lack the authority of law: it is often mistrusted and its source misplaced. From the mother's moans in A Sicilian Romance (1790) to the threatening, disembodied, and cautionary voices of The Italian (1797), the acousmatic voice lacks the agency to command in Radcliffe. Mirroring her novels' tendency to resolve themselves through the construction of a sanitizing frame of romance, Radcliffe's preference for the explained supernatural, ultimately, robs the disembodied voice of its alterity. Radcliffe, too, consistently aligns the voice with the character of its bearer: a move that, at least when considered through the theoretical lens of Mladen Dolar's (2015) recent writings on the object voice, we can take as demonstrating a preference for the fantasy of the voice-as-self. The acoustics of the Gothic Romance, as I argue below, are consequently shaped by the distinct ways in which the terror and horror literatures of the period negotiate and stage the alterity of these object voices.

\section{The disembodied voice in The Gothic Romance}

Sustained scholarly engagements with an acoustics of the Gothic Romance are rare. In perhaps the most notable reading thus far in the field, Dale Townshend draws a parallel between the poetics of sound in Romanticism ${ }^{4}$ and the acoustics of terror in the Gothic; one that comes to prominence in those gloomy scenes in which the gaze is obscured or thwarted in the Gothic. Citing the 'deep hollow groan' that emanates from the vaults of Anna Laetitia and John Aikin's 'Sir Bertrand, a fragment' of 1773, Townshend argues convincingly that 'supplementing the gaze in those places to which visibility cannot extend itself, the mere prominence of sound and noise in late eighteenth-century Gothic fiction already seems to point to a certain blindspot within the visual field' (2005: para 15). In a particularly crucial change in register from the visual to the auditory, Townshend notes that in Radcliffe's The Italian - as the novel's chivalrous hero Vivaldi journeys to the Villa Altieri - 'the haunting of the apparition is achieved solely through the powers of the voice' (2005: para 11). The acousmatic forewarnings by a shadowy monk to Vivaldi of a trauma that is yet to be

\footnotetext{
${ }^{4}$ Evident, for example, in the creative metaphor of the Aeolian harp, with its 'soft floating witchery of sound' (Samuel Taylor Coleridge, cited in Townshend 2005: para 8), or in William Wordsworth's meditations upon a metaphysics of the sonic realm in 'On The Power of Sound' (1835).
} 
witnessed are exemplary of Radcliffe's acoustics of terror, an aesthetic in which she eschews the grotesque visual horrors of Matthew Gregory Lewis' The Monk, if only, paradoxically, to allude to them, so that the 'eye of readerly engagement in Lewis' becomes 'the ear of attentive listening in Radcliffe' (2005: para 11). Now a decade old, the attention that Townshend drew to the acoustics of the Gothic Romance remains to be expanded upon by scholars in the field.

As I argue below, the acoustic dimensions of the Gothic Romance are central to its aesthetics of terror and horror. From the spectral voices of The Black Penitents in The Italian to the interrogators of the Inquisition as it is staged in Melmoth the Wanderer, as well as in the mother's moaning in Radcliffe's A Sicilian Romance, these auditory assaults compel but do not command their addressees. There is a clear link, here, to Horace Walpole's play of incest and betrayal The Mysterious Mother (1768); one which is explicitly acknowledged and to a degree constituted - by Radcliffe's citing of Walpole as her epigraph to the opening chapter of The Italian. Walpole's lines read: 'What is this secret sin; this untold tale, / That art cannot extract, nor penance cleanse?' (cited in Radcliffe 1998: 5). Elizabethan in form, this interrogation is delivered by the catholic friar Father Benedict in Walpole's transgressive play and it presents to the audience a failure of the ritual of confession to extract the incestuous secret of the Protestant Queen of Narbonne. With its thunderous, off-stage acoustics, Walpole's fiercely ideological work emphasises the distinction between the internal Protestant voice of divine conscience, on the one hand, and the interrogative spoken confessions of Catholicism on the other. In Protestantism, the voice of conscience comes from within, whereas Catholicism privileges oral confession and situates the voice as an innate identifier of the pennant, religious subject. That many of the most renowned Gothic Romances stage powerful disembodied voices as ultimately powerless to control the subjects that they address coheres with the Protestant, Gothic ideology of the late-eighteenth century that staged inquisitions in order only to demonstrate their hypocrisy and futility, and to show them as 'the very antithesis of modernity's legal reforms and due process' (Hoeveler 2012: 2).

The distinctions that are evident between Radcliffe's two most notable invocations of the acousmatic voice - the mother's moaning that resonates throughout the castle Mazzini in $A$ Sicilian Romance and the cautionary warnings given to Vivaldi by his malign pursuer in The Italian - embody a dualism that is particularly important to the Gothic: the split between the voice's ethical potential to reveal transgenerational secrets, on the one hand, and its interrogative, claustrophobic effect on the other. Radcliffe's incarnations of the voice here may be understood in terms of the respective generic, historical and aesthetic contexts of the texts in which they appear. A Sicilian Romance is foundational to the Female Gothic mode and in her unearthing of, and resistance to, paternal tyranny, its heroine Julia comes to inhabit a 'valorized masculinized role and identity' (Hoeveler 1998: 32). Resisting, as she does, her father's - the Marquis de Mazzini's - imperative to marry the tyrannical Duke du Luovo, Julia challenges paternal law so as to maintain her virtue and reason in the face of male sin and depravity. In Radcliffe, the heroine's desire must be kept in check as she walks the tightrope of what Robert Miles has identified as the tribulations of the 'hygienic self', where the heroine consistently demonstrates through her actions 'a proper conflict between desire and repression' (2002: 52). As the narrator to A Sicilian Romance counsels, 'Passion, in its undue influence, produces weakness as well as injustice' (Radcliffe 2008: 25). A past injustice, ultimately discovered, is that the Marquis de Mazzini has imprisoned his first wife Louisa Bernini - the mother of Emilia, Julia and Ferdinand Mazzini - in the dungeons beneath his castle's southern rooms. The acousmatic voice plays a crucial role in suggesting male tyranny in the text, yet 'the low hollow sound' (35) of the imprisoned mother's moaning that resonates through The Castle Mazzini is a-symbolic in nature and its ethical message 
unclear. Setting a precedent for Radcliffe's fiction, the call of the acousmatic voice here does not beckon towards a workable process of recognition and justice; instead, it presents a demand that is a-symbolic and outside of juridical language.

Cohering with Radcliffe's distrust of supernatural fancies, part of the ethically ineffectual nature of the mother's cries reside in the propensity of her terrified listeners to ascribe the acousmatic voice, as they hear it, to a spectral source. As Ferdinand -- Bernini's son and Julia's bother - is imprisoned in the vaults of Mazzini he is startled by his mother's cries that interrupt the deadly quiet of his dungeon:

the stillness of the place was suddenly interrupted by a low and dismal sound. It returned at intervals in hollow sighings, and seemed to come from some person in deep distress. So much did fear operate upon [Ferdinand's] mind, that he was uncertain whether it arose from within or from without. He looked around his dungeon, but could distinguish no object through the impenetrable darkness. As he listened in deep amazement, the sound was repeated in moans more hollow.

(Radcliffe 2008: 96-7)

If, following Mladen Dolar, we understand the mother's voice as 'the first representation of the dimension of the other' for a child, where it acts ambiguously as both 'nest' and 'cage' (2006: 41), then Ferdinand's uncertainty over whether the sighs arise from 'within or without' his prison suggests an unconscious recognition, in this dark and womb-like space, of the timbre of his mother's voice. Yet, given its 'hollow' and a-symbolic nature, Ferdinand attributes the pitiful wailing to the supposed ghost of Castle Mazzini, 'the restless spirit of the murdered Della Campo' (Radcliffe: 2008: 97). Such an erroneous sourcing of the voice to supernatural causes suggests not merely a structural failure in the call of the distressed, acousmatic voice to claim justice, but also that Ferdinand - in his role as listener - has demonstrated a weakness in character. For Radcliffe, it is only 'vulgar minds' that receive 'any species of the wonderful [...] with avidity' (Radcliffe 2008: 10); the potential for the voice to realise justice is thus significantly diminished as it is sourced to a ghostly visitant by the foreign, catholicised propensity to assume the irrational. Even Ferdinand - whose mind is said to be 'highly superior to the general influence of superstition' (Radcliffe 2008: 97) reads the acousmatic voice as confirmation of his tyrannical father's tales of past, ghostly transgressions in the castle; such tales of terror had been chosen, Radcliffe's narrator tells us, with 'some art' and 'calculated, by impressing terror, to prevent farther enquiry' into the Marquis' incarceration of the marchioness (Radcliffe 2008: 195). Clearly, then, it is the radical, a-symbolic alterity of the mother's wailing that allows the Marquis to maintain his secret. If, as Isabella van Elferen has noted, the disembodied voice is 'at once the most eerie and the most certain indicator of ghostly presence' (2012: 21), then Radcliffe plays upon this expectation to demonstrate that the marchioness, as ghost, has been stripped of her identity and marginalised politically. After Julia encounters her mother in her cell, the latter recounts once being allowed by a servant, Vincent, to view - from a distant window - her daughters leaving Mazzini; in this momentary reprieve from her imprisonment, the marchioness gains a glimpse of her children in 'the full light of day' if only to lament that those who could save her were at 'too great a distance for my weak voice to reach' (Radcliffe 2008: 178). Thus, during her imprisonment, the marchioness' voice is enfeebled, as well as being neither recognised nor sourced. It is the voice of the tyrant, instead, that carries with it the force of authority. The Marquis de Mazzini soon approaches the cell of the marchioness and 'the voice of her father' leaves Julia, now hiding close-by, 'thrilled [...] with a universal tremour; the dread of discovery so strongly operated upon her mind' (Radcliffe 2008: 175). 
The marchioness' wailing demonstrates her non-identity in A Sicilian Romance. The self is, therefore, innately tied to the character of the voice and this coupling sets a precedent for the acoustic concerns of Radcliffe's The Italian. Those few scholars who have worked on reading an acoustics of the Gothic Romance agree that in her fifth novel Radcliffe substitutes the visceral, corporeal transgressions of the perverse, fallen Ambrosio from Lewis' The Monk (1796) for less obscene, sonic terrors. What has not been considered is that after the crucial, epigraphic reference to Walpole's The Mysterious Mother, Radcliffe's opening in The Italian demonstrates, even more clearly, the voice-as-self coupling that she developed in A Sicilian Romance. In this early encounter, it is Vivaldi's valorous desire for Ellena's voice that sets in motion his pursuit of her:

The sweetness and fine expression of [Ellena's] voice attracted his attention to her figure, which had a distinguished air of delicacy and grace; but her face was concealed in her veil. So much indeed was he fascinated by the voice, that a most painful curiosity was excited as to her countenance, which he fancied must express all the sensibility of character that modulation of her tones indicated. He listened to their exquisite expression with a rapt attention, and hardly withdrew his eyes from her person till the matin service had concluded.

(Radcliffe 1998: 5)

The 'rapt attention' that Vivaldi pays to Ellena's speech finds its visual correlate as he gazes upon her person. The eroticisation of the veiled figure, resonating as it does with Eve Sedgwick's seminal reading of the veil in the Gothic as 'suffused with sexuality' (1986: 143), here, in Radcliffe's Gothic acoustic, relies primarily upon the voice as the love object that ignites Vivaldi's passions. Ellena's veiling promotes a misrecognition - one supported by Radcliffe's rendering of her heroine - that the beloved's voice is a marker of both her beauty and her character. This voice-as-self dynamic resonates with Mladen Dolar's recent comments that the 'unique fingerprint quality to the voice' - its 'singular tonality, accent, pitch and timbre' - renders it as 'something profoundly individual' where this subjectivized voice is 'accompanied by fantasies of ineffability and preciousness, the invaluable value of individuality' (2015: xii). Yet, the voice as a love object and as the unique fingerprint of the self are two fantasies that mask its innately traumatic character and core. In his encounters with the 'tremendous voice' of Schedoni (1998: 105) and his subsequent interrogations by the cult of the Black Penitents, Vivaldi is later exposed to the vicissitudes of the object voice as it pertains to the confessor and his agents. The most notable instance is the misconstrued warning Vivaldi receives from a shadowy monk on his approach to Ellena's home: "Go not to the villa Altieri [...] for death is in the house!" (41). Tellingly, this portentous warning is misunderstood; Vivaldi continues his passage to Altieri, terrified as he is, to find that it is not Ellena who has been murdered, as he had wrongly anticipated, but her aunt Signora Bianchi. That Vivaldi, too, suspects wrongly that this voice belongs to Schedoni, rather than to its bearer Nicola di Zampari, suggests Radcliffe's denial of the ethical significance of the acousmatic or obscure voice. Yet, the fantasy of the voice-as-self - of Ellena's sweet tones mirroring her honest character - is maintained in the text as part of its rendering of a sanitizing frame of romance.

While it may share a distrust of the catholicised, disembodied voice, the literature of horror exposes the perils of the voice-as-self fantasy more readily. Indeed, it is in the now mythic tale of Mary Shelley's Frankenstein that we find an exemplary account of its difficulty. From its first animation, the creature's verbal expression is never portrayed as 
monstrous, which is evident in Victor Frankenstein's account to Walton of the moment when he was first filled with horror at the sight of his progeny:

I beheld the wretch -- the miserable monster whom I had created. He held up the curtain of the bed; and his eyes, if eyes they may be called, were fixed on me. His jaws opened, and he muttered some inarticulate sounds, while a grin wrinkled his cheeks. He might have spoken, but I did not hear; one hand was stretched out, seemingly to detain me, but I escaped, and rushed downstairs.

(Shelley 2003: 59)

Privileging the visual over the auditory realm in his description, Victor is compelled to flee the gaze of his creature before he may discern whether it 'might have spoken'. As with the 'hollow' moans of the marchioness in A Sicilian Romance, the creature's non-identity is conveyed through a failure of the voice to articulate words. At times a reflective and articulate being, Shelley's monster is able to later deduce that his appearance is primarily what makes him an affront to society; as he watches the De Lacey family, for instance, he demonstrates 'sagacity enough to discover' that his 'unnatural hideousness' of appearance is 'the chief object of horror with those who had formerly beheld' him. Importantly for this discussion of the false understanding - conscious or otherwise - of the voice as self, the monster reflects, too, that his 'voice, although harsh, had nothing terrible in it' (2003: 134-5). It has been noted that as a monstrous hybrid -- part-human, part-animal in form - the creature's 'narcissism is [...] thwarted from the outset' (Dolar 1991: 16). Yet, the monster's identification with its own civilized voice is a narcissistic misrecognition of its voice-as-self: a hopelessly ill-fated fantasy that dissolves as soon as it is tested through the encounter with De Lacey in which he is chased from the family's home by Felix. The monster embodies a zero-point of subjectivity - he represents a traumatic core of non-identity - and has been, since birth, the bearer of an impassable and traumatizing gaze that paroles Victor (Dolar 1991 20). Thus, Frankenstein does not rely upon the voice as an object of horror, per se, but instead dissolves the fantasy of the subject-as-voice. Yet, in the reading of Melmoth the Wanderer that closes this article, which I set-up in the following section, I argue that the Gothic Romance does invoke the acousmatic voice as a horrific and an "uncontrollable excess" (Botting 2015, p.99) and that this traumatising object voice is, ultimately, sublime in character.

\section{The negative sublime and the Gothic}

If the sublime may be said to form part of a shared 'aesthetic history' between the Gothic and Romanticism (Botting 2013: 13), then it is clear that the Gothic has long had an interest in its negative aspects in particular. Cohering with the male Gothic's predilection for horror, an experience of sublime awe may be 'crushing or engulfing' and mark a moment for the subject at which 'the power of an object or event is such that words fail at points of comparison disappear' (Shaw 2006: 2). That the sublime may overpower the subject by exposing them to an arena of feeling that is beyond language - a conceptual space of wonder that exceeds discourse and which either erases the subject's sense of self or, at the very least, renders the self as miniscule, insignificant - is one common to its Romantic, eighteenthcentury conceptualisations. In the Gothic, though, this experience often does not lead to the attainment of a higher knowledge, as it may do, for instance, in the poetry of William Wordsworth; it fails to resolves itself through epiphany, bringing to the fore, instead, an uncanny dissonance. For Robert Miles, it is a 'hermeneutics of desire' that drives the fearful, 
uneasy sense of the sublime in the novels of Ann Radcliffe. He argues that 'the Gothic and Romantic sublimes take alternative turnings', where, in particular,

the Gothic sublime is closely linked to the uncanny, the moment when the homely, or familiar, repressed and made strange, reappears within narrative repetition. The uncanny reveals the self, to itself, as no longer the master of its own house.

(Miles 2002: 63-4)

It is not only in Radcliffe that we may see this dynamic at work of course; in Shelley's Frankenstein, Victor, in a moment of relief from his torment, isolation and angst, is overwhelmed by the sublime awe of the Alps. Enraptured by an ecstatic experience of transcendence, he is struck by the 'awful majesty' of Mont Blanc, the towering image of which creates a 'wonderful and stupendous scene' that both consoles and elates him: 'My heart, which was before sorrowful, now swelled with something like joy' (Shelley 2003: 101). If Victor's response to the majesty of Mount Blanc is typically Romantic then the interruption to his joy is painfully Gothic as he sees his monstrous, uncanny creature hurtling towards him 'with superhuman speed' (ibid.). Cognate with Miles' understanding of an uncanny sublime, a distinctly Romantic experience of transcendence through nature is disrupted by a Gothic agent of malignity.

An influential Romantic account of the sublime, Edmund Burke's A Philosophical Enquiry into the Origin of our Ideas of the Sublime and the Beautiful (1757) pays but brief attention to a sublime experience that is auditory in nature. 'The eye is not the only organ of sensation by which a sublime passion may be produced,' Burke confidently argues; where, more specifically, it is a series of gargantuan, a-symbolic sounds that 'have a great power in these as in most other passions' (1958: 82). Burke continues with a caveat that he applies to the distinction between words and 'excessive loudness':

words do not affect simply by their sounds, but by means altogether different. Excessive loudness alone is sufficient to overpower the soul, to suspend its action, and to fill it with terror. The noise of vast cataracts, raging storms, thunder, or artillery, awakes a great and awful sensation in the mind, though we can observe no nicety or artifice in those sorts of music. The shouting of multitudes has a similar effect; and, by the sole strength of the sound, so amazes and confounds the imagination, that, in this staggering and hurry of the mind, the best-established tempers can scarcely forbear being borne down, and joining in the common cry, and common resolution of the crowd.

Burke points towards a sublimity of pure sound; an experience that is not split or diluted by the power of words to signify. He emphasises a terror in which the soul is 'overpowered' rather than expanded; yet we may understand in the 'raging storms', 'thunder', and 'vast cataracts' of the Gothic, that, at least as they may be rendered in the literary aesthetic, there is a more exultant side to this terror. Elsewhere in his enquiry Burke emphasises that 'the ideas of pain are much more powerful than those which enter on the part of pleasure' (1958: 39). Burke's insistence upon sublime suffering seems to resist Radcliffe's famous reading of his writing that supports, or sets a precedence for, her distinction between terror and horror in 'On The Supernatural in Poetry' (1826). The former affect, according to Radcliffe, positively 'expands the soul, and awakens the faculties to a high degree of life', while the latter 
obscenity 'contracts, freezes, and nearly annihilates' the faculties. Radcliffe continues, 'I apprehend, that neither Shakspeare [sic.] nor Milton by their fictions, nor Mr. Burke by his reasoning, anywhere looked to positive horror as a source of sublime, though they all agree that terror is a very high one' (2000: 168). Yet, for Burke, horror does present the opportunity for sublime experience and in this formulation we may include frightened reactions to excessive loudness.

Burke's writing on the sublime, too, implies an important parallel between the torturous scenes so familiar to, say, the Male Gothic's many figurations of the Spanish inquisition, and the sublime power of suffering: it is pain's paradoxical stance as 'stronger in its operation than pleasure', while being a lesser evil than death itself, that marks the latter as a beyond that is more horrendous even than the pain of corporeal suffering; 'death', he posits, 'is in general a much more affecting idea than pain; because there are very few pains, however exquisite, which are not preferred' to it (Burke 1958: 39-40). Burke argues:

The passion caused by the great and sublime in nature, when those causes operate most powerfully, is Astonishment; and astonishment is that state of the soul, in which all its motions are suspended, with some degree of horror. In this case, the mind is entirely filled with its object, that it cannot entertain any other, nor by consequence reason on that object which employs it.

While we may use Burke's writing to emphasise horror's potential for sublimity, we may contest his notion that 'words' do not affect the hearer by their sounds, particularly in light of psychoanalytic understandings of the object voice. Words, which by definition signify and form part of meaningful social exchange, are carried, paradoxically, by the troublesome, asymbolic timbre of the voice; this is what Mladen Dolar describes as the 'dimension of the voice' that is 'against logos, the voice as the other of logos, its radical alterity' (2006: 52). In the classical sublime, at least as it was posited by the Greek critic Dionysius Longinus in the first century AD in his Peri Hypsos or On Sublime, the rhetorical power of words are central to a more dangerous conception of logos. As Philip Shaw summarises,

for Longinus, the discourse of the sublime, whether in political oratory or in epic verse, works to overcome the rational powers of its audience, persuading them of the efficacy of an idea by means of sheer theoretical force. In Longinus' view [...] listeners and readers are ravished or, most disturbingly, raped by the power of words.

(Shaw 2002: 4-5)

We may explore this dimension of the sublime in Melmoth the Wanderer by positing that the voice in the male Gothic holds - as an agent of horror - a particular means of diabolical interrogation; that the voice may 'ravish' and 'rape', certainly, suggests the potential for its 'negative' sublimity.

After citing 'awe and wonder' as one of the many negative affects that populate its pages, Fred Botting has suggested that in the Gothic,

The negative aspect of intense emotions is not simply a sign of the loss or absence of rational judgement. Reason is over-whelmed by feeling and passion, and signalled as a horrified, paralysing encounter with something unspeakable, an obscure presence 
too great to comprehend evoking an excess of feeling or registering an experience too intense for words.

Drawing from Botting's emphasis upon the Gothic victim being 'over-whelmed' by an encounter with an 'unspeakable' presence, particularly in light of Longinus' argument that sublime rhetoric may 'ravage' its listener, allows us to situate this negative, timbral sublime in a different theoretical register to the Kantinian perspective of Vijay Mishra's The Gothic Sublime (1994): a text which remains, until this day, of paramount importance to the field of Gothic studies. In drawing form Jacques Derrida's commentary of Kant's Critique of Judgement (1790) - as it is articulated in Derrida's collection The Truth in Painting (1987) Mishra argues that an opening-up of an apocalyptic, end-times for the subject - where it may be annihilated - is one of the sublime's most potent and disturbing effects. Mishra argues of the Gothic sublime that, 'it is the threat of apocalypse that is the spectacle of the sublime; it is the threat of self-extinction and 'self-dissolution' that forces the subject to retreat back into the comfortable frame of the beautiful' (1994: 227). He further notes that, 'The alteration between [...] the positive and negative sublimes, is an essential feature of Radcliffe's Gothic vision,' where even the 'positive' sublime is consistently 'invaded by its opposite, its counterforce, its negative' (1994: 237). Yet, through its various stagings of entrapment and interrogation, Melmoth - a text that is perhaps emblematic of Male, paranoiac Gothic suggests that there is no turning away from the timbral 'negative' sublime of interrogation. Mishra reads Melmoth as representing an 'end of history' in which Maturin's fractured narrative can only 'frame' Melmoth and 'cannot totalize or "present" him to consciousness' (1994: 247). By inference, then, there is something too demonic - too overwhelming - about Melmoth and, much like the troublesome traumatic kernel of the voice as it is figured in recent psychoanalytic studies, Melmoth's almost supernatural character implies that his infernal being is beyond representation. ${ }^{5}$

\section{The 'negative' timbral sublime in Melmoth the Wanderer}

Regarded as the last notable text in the Walpolean school of the British Gothic period, that is 1764-1820, Melmoth is a complex tale weaved around the vicissitudes of a Faustian pact. Its Gothic shades include the revelation of transgenerational secrets to the protagonist John Melmoth after he beholds a mesmerising portrait of his ancestor. The image of the man in the painting suggests 'nothing remarkable' in his 'costume' or 'countenance', but 'the eyes, John felt, were such as one feels they wish they had never seen, and feels they can never forget' (Maturin 1998: 17-8). Revealed in an uncanny mise-en-scène close to his uncle's death bed, John discovers that his ancestor Melmoth, recalling the figure of the wandering Jew, still walks the earth disquietedly, seeking to persuade those whom he encounters to assume his role in an infernal pact that has unnaturally sustained his life. As he laments to John towards the novel's gruelling ending, Melmoth, ultimately, has 'traversed the world in [this] search, and no one, to gain that world, would lose his own soul!' (Maturin 1998: 538). His infernal rhetoric is thus a failure of sorts; an auditory assault that has persecuted but not persuaded others to take his place as Faust. Melmoth does not merely seek a confession - as an Inquisitor may - but a dedication to future torment: the interrogated must agree to become him. Reiterating this sense of language as failing, the original seduction of Melmoth by the rhetoric of the devil remains unheard, and its reproduction by Melmoth is impossible.

\footnotetext{
${ }^{5}$ Given that his analysis of Maturin's text forms part of a wider sweep of the period, Mishra does not define the exact contours of the 'negative' sublime in Melmoth or provide any analysis of the timbral sublime.
} 
As a figure of eternal obscenity, critics, as well as writers as esteemed as Honoré de Balzac, have been drawn to Melmoth as the archetypal outsider: an infernal incarnation of the Byronic archetype. Recalling also the foreign, male tyrant of the Gothic Romance, he takes a perverse enjoyment in witnessing the horrors that may befall others. As Stanton recalls with astonishment in his manuscript, Melmoth laughs heartily while 'gazing on the lifeless bodies' of two lovers whom 'lightning had struck and blasted' (Maturin 1998: 39). Indulging in horrors that seem, at least at first, to be radically different to the veiled terrors of Ann Radcliffe's Gothic Romances, Maturin's most-read novel is considered by critics to be a 'paranoiac text, in which malevolence becomes its own justification' (Punter 1996: 128). Comparable, in this guise, with William Godwin's Caleb Williams (1794) and James Hogg's The Private Memoirs and Confessions of a Justified Sinner (1824), Melmoth forms part of a body of Gothic texts of the late-eighteenth and early-nineteenth centuries that, in their intense and sustained focus upon psychopathology and narrative truth, suggest an 'increasing complexity of verification' in the literature of the period, which is achieved, partly, by their concern with the 'ambivalence of persecution' (Punter 1996: 136). ${ }^{6}$ In the course of pursuing my argument regarding the voice-as-self above, I have drawn from Shelley's Frankenstein, but there is an equally important Godwinian context, too, that resonates strongly with the perverse laws of Melmoth the Wanderer. As Sue Chaplin suggests, the many confrontations with the machinations of the law as it is staged in Godwin or in Maturin invokes a particular historical understanding of the 'juridical subject' of the early nineteenth-century who is, by association, a 'guilty subject' caught-up in 'a modern juridical force that reproduces its authority through the construction of a deeply conflicted, abject juridical subjectivity' (2007: 143). In her Žižekian reading, Chaplin recognises that 'Gothic fictions bring to the fore the law's obscene dimension' where Melmoth as a 'labyrinthine text', in particular, 'frustrates and persecutes its reader' (2007: 153). One source of this frustration is the dimension of the text that - given its multiple embedded narratives - 'debunks the illusion of the "neutralobjective point of view" and so leaves the reader open to encountering a troubling alterity of perspective in their very act(s) of reading (Leach 2011: 23). Cohering with, yet extending Chaplin's psychoanalytically-informed argument, of interest here is not only Melmoth's status as a persecutor and as the obscene supplement to law but, more specifically, it is that his voice forms part of the persecutory process that Melmoth calls upon to torment his subjects. While, at least theoretically, the word or 'logos' may be understood as 'law', we will see that the surplus of law - its obscene dimension - relies upon the voice to assert itself and to dominate the guilty, juridical subject. Melmoth's auditory means of persecuting others - and the correlative malign acoustics of Maturin's novel as a whole - have yet to be fully explored in scholarly readings, but Peter Weisie has recently suggested that Maturin's text 'demonizes the pure enunciation of the object voice' in order to show that 'the dependence of a stable political system' relies upon 'its rejection' (2015: 51).

Recalling Burke's reading of horror and pain as potential sources of the sublime, the victims of interrogation in Melmoth - those subjects who are compelled to confess or to yield by a typically Gothicized, perverse figures of law - are awe-struck by the torturous excesses of forced confession and the object voice's role in attempting to secure it. Cohering, too, with Longinus' attention to the rhetorical sublime, these men are 'ravished' by the terrible oratory means of their inquisitor. The context that Maturin creates for this invocation of the sublime voice of interrogation is a carefully rendered acoustics of entrapment. Take, for instance, the

\footnotetext{
${ }^{6}$ Cohering with Punter's account, Chris Baldick situates the novel as not simply the last notable story in the genre of the Gothic Romance, but as involved in a more particular aesthetic movement of its historical moment alongside those most notable novels of Godwin, Hogg and Mary Shelley (Baldick 1998: ix).
} 
disembodied voices that visit Monçada in his cell after he hallucinates the image of a sublimated, divine love object:

For a moment I almost believed in the actual presence of this glorious visitor [the mother of God], but just then the voice was heard louder than ever, 'Spurn them, spit on them, - you are mine, and I claim this homage from my vassal.' At these words the figure disappeared instantly, and the voice was soon renewing its whispers, but they were repeated to an insensible ear, for I fell into a swoon.

(Maturin 1998: 157)

The voice here acts to exorcise the fantasy of the elevated, ghostly lady, and instead reveals the traumatic core that this sublimation - as a phantasmatic screen - works to cover-up; it is, too, merely one example of the myriad voices that populate the dungeons of the Inquisition. Later in 'The Spaniard's Tale', Monçada is led to a church altar where, already disorientated from his capture, he experiences law and authority as pure voice: 'I approached the altar and attempted to kneel,- - an invisible hand repelled me. A voice seemed to address me from the recesses of the altar, and demand what brought me here?' (Maturin 1998: 183). This encounter is framed by an earlier invocation of the 'thundering voice' of his Superior who, when he addresses them at matins, leaves his monks 'shuddering' with the 'terrible sounds' of his calls for penance (Maturin 1998: 149). The textual acoustics of such moments integrate classical and Romantic understandings of the sublime by rendering the voice as 'thunderous'. Those interrogative words that ravish take on, metaphorically, a terrible sublimity that recalls the vast soundscapes cited in Burke's Enquiry. Resonating with Melmoth's interrogation of Stanton while he is trapped in an asylum, an important part of which I cite as the epigraph to this article, the voice takes precedence here as the entire phenomenality of the interrogator's presence. ${ }^{7}$ In turn, Melmoth's promise to Stanton that 'my voice shall ring in your ears' does not merely describe a particular intersubjective demonstration of power in the text; its force is mirrored in the other voices of the (tyrannical) Catholic persecutors who interrogate Monçada. As psychoanalytic theory consistently argues, the object voice may 'throw' itself into others' mouths through acts of ventriloquism and its cause seems always insufficient to produce its effect (Dolar 2006: 67). In this instance, its traumatic core is displaced from the infernal Wanderer to those who seek confession through Inquisition. Thus, Monçada is subjected to an acoustics of imprisonment where, by night, he is sleep-deprived by the acousmatic whispers of Melmoth - these "terrible sounds were re-echoed in my dreams" recalls the Spaniard (Maturin 1998: 156) - and where, by day, he must face a Superior whose sublime rage is described as 'majestic and overwhelming' and who boasts that his "voice might summon half to the convent to seize you this moment" (Maturin 1998: 208). As an excessive sensory assault, such torture resonates with horror's predilection for an overwhelming of its victims, where in Melmoth the horrific effect is produced by a redoubling of the sonic rather with the visual realm.

Further horror lies in the possibility that the object voice - set free from its moorings in the body - may overwhelm the very frame of textual representation itself. This is exactly the point at which we encounter the 'negative' timbral sublime at its most dangerous. In a

\footnotetext{
${ }^{7}$ Long recognised by critics, Maturin's pervasive distrust of organised religion reverberates through his novel's acoustics and, in particular, the parallels made between the primacy of the object voice - and its associated traumatic core - in both demonic (Melmoth) and establishment modes of interrogation (The Inquisition). Maturin's central source for the horrors of the Inquisition was Johann Lorenz von Mosheim's account in Institutes of Ecclesiastical History (translated into English from the original Latin in 1764).
} 
diabolical rendering of the voice-as-self, Melmoth's infernal voice marks his identity as a radical, spectral other:

The rest of his figure, enveloped in darkness, gave to this bodyless and spectre head an effect truly appalling. The ferocity of his features, too, was softened into a heavy and death-like gloom, as he repeated, 'We part never, --I must be near you for ever,' and the deep tones of his voice rolled like subterranean thunder round the church. A long pause followed. He continued to stand in the same posture, nor had I power to change mine.

(Maturin 1998: 187)

The acousmatic voice of perverse law, here, is shown in its full splendour. This Gothic invocation of the timbral sublime - the thunderous object voice that threatens its very frame of representation - is traceable to Renaissance drama. The thunder strikes in Revenge Tragedies when excessive and violent recompense is imminent. In Cyril Tourneur's The Revenger's Tragedy (1606), for example, a group of disguised revengers, led by the brothers Vindice and Hippolito, murder a troupe of nobles dining with the lustful and cruel Lussorio. The thunder duly strikes in appreciation of the slaughter:

[...] these four kill the four at the table, in their chairs. It thunders. VINDICE: Mark, thunder!

Dost know thy cue, thou big-voiced crier?

Dukes' groans are thunder's watch words.

HIPPOLITO: So, my lords, you have enough.

VINDICE: Come let's away-no lingering.

HIPPOLITO: Follow, go!

Exeunt. [VINDICE remains.]

VINDICE: No power is angry when the lustful die:

When thunder claps, heaven likes the tragedy.

Exit VINDICE.

(Tourneur 1969: 132-133)

In Jacobean revenge tragedy the heavens revel in excess as 'when thunder claps, heaven likes the tragedy'. Vindice's reading of this thunderous acoustic as an endorsement of revenge is narcissistic but also fatalistic as it beckons towards his own fate. It resonates, too, with Count Lodovico's dry observation early in John Webster's The White Devil (1612) that ' $\mathrm{t}] \mathrm{he}$ violent thunder is adored by those/ Are pash'd in pieces by it' (Webster 1969: 143). Vindice's very allegiance to the law of thunder suggests that he will be undone by it. This is the exact contours of the Faustian pact. As Faust, Melmoth's status as a perverse supplement to law, which is mirrored by The Inquisition's torturous enticement of false confession, means that his sublime tale may never fit the frame of sophistic representation that could seduce, rather than overwhelm, those whom he pursues. Thus, the acousmatic voice - in a surprising dynamic that recalls Radcliffe's distrust of it - fails to persuade those whom it calls to in Melmoth. The timbral sublime is almost too much for the subject of interrogation to bear - it takes their selfhood to the very edge of annihilation - and, ultimately, it fails to penetrate and ventriloquize the inner voice of conscience of those who it interrogates. 


\section{Conclusion}

In his much-cited introduction to The Oxford Book of Gothic Tales, Chris Baldick contends that Gothic 'should combine a fearful sense of inheritance in a time with a claustrophobic sense of enclosure in space, these two dimensions reinforcing one another to produce an impression of sickening descent into disintegration' (1993: xix). The disembodied voices of the Gothic Romance may contribute to producing both of these effects. There is a fearful sense of a malign 'inheritance' rendered in Radcliffe's, ultimately explained-away, acousmatic voices; while in Maturin's Melmoth the 'claustrophobic' sense of enclosure of the madhouse or the Inquisitorial vault may be redoubled by the roar of an interrogator's voice. The literature of horror, first exposing the narcissistic fantasy of the voice-as-self in the rejection of the monster by the De Laceys in Mary Shelley's Frankenstein, does not resolve the alterity of the object voice. In Melmoth its traumatic potential is shared between the novel's antagonists and the voice remains anterior to logos: a bearer of a perverse law of excess. Its rendering may cohere with critical understanding of the 'negative' sublime but, ultimately, the voice fails to elicit the response it desires from those who are interrogated so as to cast into doubt the entire ritual of the confessional. Importantly, the examples of the disembodied voice cited here from the Female and Male Gothic modes suggest distinct differences between the object voice's invocation in terror and in horror fiction. In the Radcliffean Gothic Romance, the disembodied voice places into question the identity of the speaker (or crier) of the utterance heard: whether that be the 'hollow' sounds that resonate throughout the Castle Mazzini or the ghostly monk's forewarnings to Vivaldi in The Italian. In a Sicilian Romance, the misunderstanding that unfolds regarding the source of the mother's moans is partly temporal in character: her voice is thought to beckon towards pastgenerational transgressions rather than present injustice. As Isabella van Elferen has suggested, 'disembodied sound renders audible the temporal dislodgement that is inherent to spectrality: it unlocks present sound from past origin, leaving that origin unheard, unsignified, non-existent' (2013: 430). Ultimately, Radcliffe puts her narrative to work so as to resolve the origin of the disembodied voice and, in so doing, her acoustics of the Gothic assist in rendering the sanitizing frame of the explained supernatural, one which closes the temporal gaps opened up by the mother's wails. There is no such clean resolution in Melmoth. At the beginning of the novel's second volume, Monçada laments to John Melmoth that words fail him as he attempts to describe the tortures that he has encountered; his trauma remains present: 'he trembled, -uttered some inarticulate sounds, -wept; - and his agitation appeared to Melmoth, with his uncontinental feelings, so violent, that he entreated him to spare the description of his feeling and proceed with the narrative' (Maturin 1998: 131). The continental tale of Monçada becomes an impossible, primal scene of myriad traumas; the 'thunderous' and acousmatic voices that he has encountered retain their alterity even when they have failed to illicit the confessions that their bearers desired. 


\section{References}

Baldick, Chris (1993), 'Introduction' in Chris Baldick (ed.), The Oxford Book of Gothic Tales, Oxford: Oxford University Press, pp.xi-xxiii.

Baldick (1998), 'Introduction', in Charles Maturin, Melmoth the Wanderer, Oxford: Oxford University Press, vii-xix

Botting, Fred (2013), Gothic, $2^{\text {nd }}$ ed., Abingdon: Routledge.

- (2015), 'Poe, Voice, and the Origin of Horror Fiction' in Jorge Sacido-Romero and Sylvia Mieszkowski (eds.), Sound Effects: The Object Voice in Fiction, Leiden: Brill Rodopi, pp.73-100

Burke, Edmund (1958), A Philosophical Enquiry into the Origin of our Ideas of the Sublime and the Beautiful, London: Routledge and Keegan Paul

Chaplin, Sue (2007), The Gothic and the Rule of Law, 1764-1820, Basingstoke: Palgrave.

Dolar, Mladen (1991), "II Shall Be with You on Your Wedding-Night": Lacan and the Uncanny', October, 58 (Autumn 1991), 5-23.

- (2006), A Voice and Nothing More, Cambridge, MA: MIT Press.

- (2015), 'Preface: Is There a Voice in the Text?', in Jorge Sacido-Romero and Sylvia Mieszkowski (eds.), Sound Effects: The Object Voice in Fiction, Leiden: Brill Rodopi, pp.xi-xx.

van Elferen, Isabella (2012), Gothic Music: The Sounds of the Uncanny, Cardiff: University of Wales Press.

- (2014), 'Sonic Gothic', in Glennis Byron and Dale Townshend (eds.), The Gothic World, Abingdon: Routledge, pp.429-440.

Hoeveler, Diane Long (1998), Gothic Feminism: The Professionalization of Gender from Charlotte Smith to the Brontës, Pennsylvania: Pennsylvania State University Press.

- (2012), 'Anti-Catholicism and the Gothic Imaginary: The Historical and Literary Contexts,' in Bret C. McInelly (ed.), Religion in the Age of Enlightenment, Brooklyn: AMS Press, pp.1-31.

Leach, Nathaniel (2011), 'The Ethics of Excess in Melmoth the Wanderer', Gothic Studies, 13.1 (May 2011), pp.21-37.

Maturin, Charles (1998), Melmoth the Wanderer, Oxford: Oxford University Press.

Miles, Robert (2002), Gothic Writing 1750-1820: A Genealogy, $2^{\text {nd }}$ ed., Manchester: Manchester University Press.

Mishra, Vijay (1994), The Gothic Sublime, Albany: State University of New York Press. 
Punter, David (1996), The Literature of Terror: Volume 1, The Gothic Tradition, $2^{\text {nd }}$ ed., London and New York: Longham.

Radcliffe, Ann (1998), The Italian, Oxford: Oxford University Press.

- (2000), 'On the Supernatural in Poetry', in E. J. Clery and Robert Miles (eds.), Gothic Documents, A Sourcebook, 1700-1820, Manchester: Manchester UP, pp.163-172.

- (2008), A Sicilian Romance, Oxford: Oxford University Press.

Sedgwick, Eve Kosofsky (1986), The Coherence of Gothic Conventions, New York: Methuen Publishing.

Shaw, Philip (2002), The Sublime, Abingdon: Routledge.

Shelley, Mary (2003), Frankenstein, London: Penguin Books.

Tourneur, Cyril (1969), The Revenger's Tragedy, in G. Salgādo (ed.), Three Jacobean Tragedies, Harmondsworth: Penguin Books Ltd, pp.41-135

Townshend, Dale (2005), 'Gothic Visions: Romantic Acoustics', Romantic Circles, available online: https://www.rc.umd.edu/praxis/gothic/townshend/townshend. Last accessed: $30^{\text {th }}$ January 2016.

Webster, John (1969), The White Devil in G. Salgādo (ed.), Three Jacobean Tragedies, Harmondsworth: Penguin Books Ltd, pp.137-258

Weise, Peter (2015), 'The Object Voice in Romantic Irish Novels', in Jorge Sacido-Romero and Sylvia Mieszkowski (eds.), Sound Effects: The Object Voice in Fiction, Leiden: Brill Rodopi pp.47-71 